\title{
Anti-Mining Conflicts and Degrowth
}

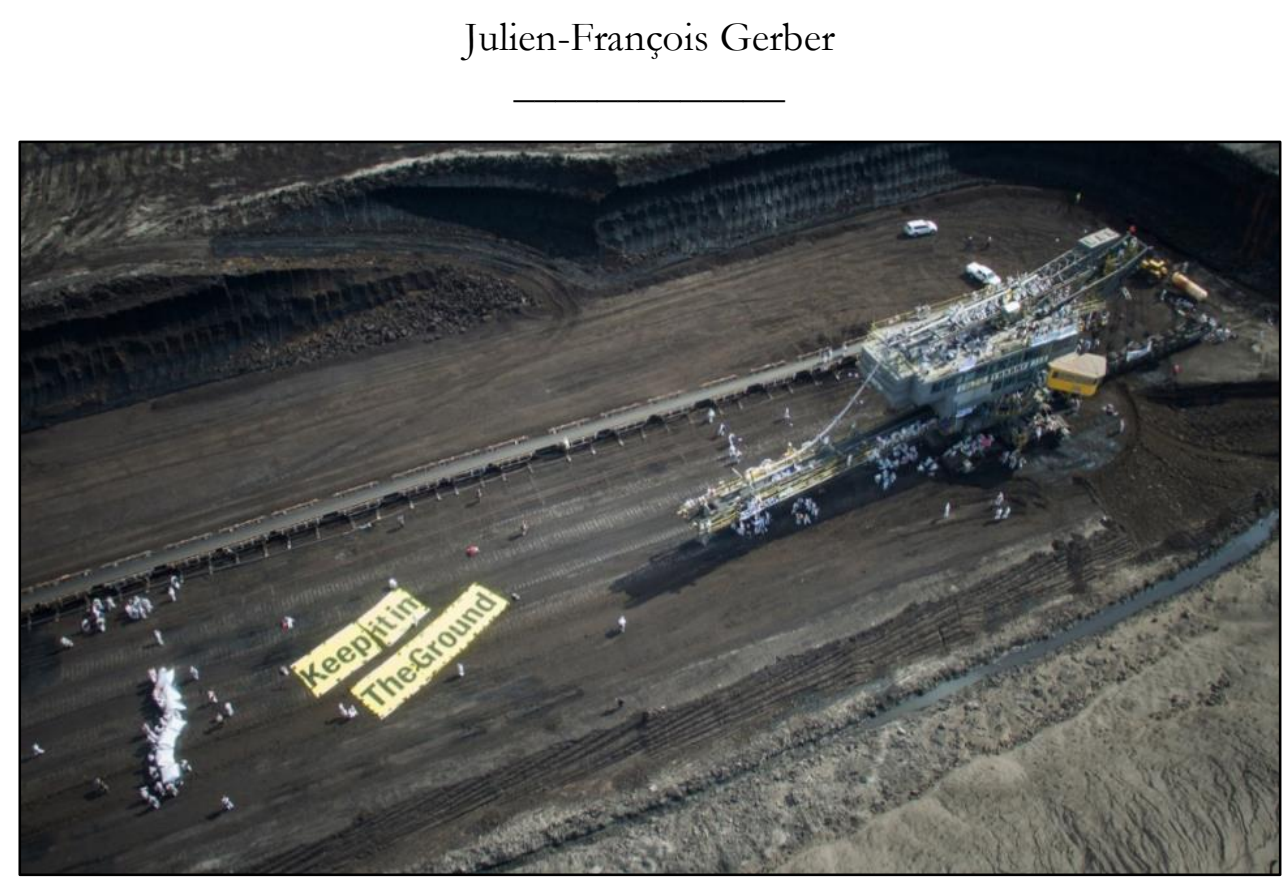

Photo: Welzow Süd opencast mine with Ende Gelände banner. Source: Rikuti, 2016.

Keywords: mining; degrowth; post-extractivism; anti-mining conflicts; convergence

$\mathrm{I}$ $\mathrm{s}$ there a collective alternative vision emerging from the thousands of people involved in mining conflicts worldwide? Are the people involved in such conflicts promoters and practitioners of more sustainable economies? And if they oppose predatory forms of economic growth, aren't they the 'natural allies' of the degrowth movement? Examining these questions will be crucial for understanding the changing nature of commodity frontiers and their eventual possible dissolution.

Whatever the answers are, it is clear that conflicts over extractivism are increasing and commodity frontiers are on an accelerated march. From the year 2000 in particular, the growth of Asian economies - especially China - has triggered an increasing demand for natural resources, pushing commodity frontiers further (Conde, 2017). India's growth, in contrast, has relied so far on

\section{Correspondence:}

Julien-François Gerber, gerber@,iss.nl

\section{Cite this article:}

Gerber, J.F. 2020. “Anti-Mining Conflicts and Degrowth.” Commodity Frontiers 1: 28-31. doi: 10.18174/CF.2020a17968.

Commodity Frontiers is an open-access journal edited by the CFI Editorial Board, Mindi Schneider, senior editor. Read it online at Commodity Frontiers, or our website, commodityfrontiers.com.

This work is licensed under a Creative Commons Attribution-NonCommercial 4.0 International License.

\section{(c) (1) (8)}


internal supplies, causing many fierce conflicts within its national boundaries (Bisht \& Gerber, 2017). Furthermore, new technologies are allowing companies to go deeper and farther, into more ecologically vulnerable regions and new areas like deep sea extraction sites.

Very often, these areas are also inhabited or otherwise used by populations who must bear the costs of pollution and destruction, and who resist accordingly.

A key finding of Conde's (2017: 81) important overview of mining conflicts is that "many movements create, recover or reaffirm a development path that rejects mining, in the process proposing alternative development models, or 'alternatives to development". Conde's overview also reveals that there has been a shift in the strategies and narratives mobilized by antimining movements in the last two decades. It appears that alliances with extra-local actors have played an important role in this shift not only launching new movements, but also developing solidarities and political opportunities, and allowing for the emergence of alternative imaginaries of development.

Many movements, it turns out, explicitly reject the broader 'development' model that is imposed upon local communities and that is based on extractivism. Conde notes that "an emerging anti-capitalist and nonEurocentric discourse articulated with local place-based demands [is increasingly visible]", but she adds that "further research on new cases and with the specific objective of identifying this trend would be welcomed" (ibid: 87). She regrets that "there is a lack in much of this [mining conflict] literature of 'strong sustainability' views that explore the possibilities of an economy less based on extractive industries" (ibid.). Such economies would fall under the headings of 'postextractivism' or of 'degrowth'.
$\mathrm{P}$ ost-extractivism, which was mainly developed in Latin America, calls for a societal change away from economies dependent on and guided by extractive industries (Gudynas, 2013), while degrowth refers to a radical politico-economic reorganization that leads to smaller and more equitable social metabolisms (Kallis, 2018).

Degrowth not only challenges the hegemony of growth, but also calls for a redistributive downscaling of production and consumption - especially in industrialized countries - as a means to achieve sustainability, social justice and well-being.

It is usually associated with the idea that 'smaller can be beautiful', but the emphasis is not on 'less of the same': degrowth promotes a society with a smaller metabolism, but more importantly, a society with a metabolism which has a different structure and serves new functions. Degrowth was launched into the political arena as a provocative slogan by environmental activists in the beginning of the 2000s and it soon became a social movement and a concept debated in academic circles. Among the different forms of post-growth, degrowth has arguably the greatest potential to be transformative and extended into a social movement.

A nti-mining conflicts, postextractivism and degrowth could indeed complement each other in important ways (Gerber et al., 2020). In a nutshell, struggles against extractivism provide a large-scale force of resistance, while post-extractivism and degrowth theorize a way towards social and ecological sustainability. There is little doubt that, taken as a whole, the myriad conflicts against various forms of extractivism represent a powerful socio-political force in the world today (see the Environmental Justice Atlas). However, this political strength has so far failed to translate into an equal strength in theoretical production, despite the fact that many creative concepts have been forged through environmental justice activism, such as 'land-grabbing', 'ecological debt', 'climate 
justice' and 'indigenous territorial rights'. Yet, there seems to be no common radical ideology emerging from all these movements.

But this is not to say that anti-mining movements lack conceptual frameworks within which the dynamics and relationships they emerge from are interpreted. Sarayaku's resistance in Ecuador's Amazon against oil exploration is a well-known example, as this community became the cradle of the concept of Sumak Kawsay, or Buen Vivir, whose influence became global. A Gandhian worldview has been mobilized in Indian conflicts, and particular cosmologies can be invoked for advocating a just order in indigenous lands. Yet, overall, many antimining struggles remain local or regional in their conceptual scope, and this fragmentation can obstruct wider synergies and the broader societal alternatives that can be imagined and constructed. In contrast, the labor movement, for instance, has given rise to rich (and at times competing) theoretical traditions, which could nourish debates and political strategies.

This is where the contribution of degrowth could be helpful. The degrowth movement has largely been an intellectual endeavor so far, albeit with numerous local experiments; but a good theory can be a powerful weapon for fostering understanding and action. The starting point of degrowth is the 'impossibility theorem', namely that the 'imperial mode of living' for a world of 8 billion people is neither possible nor desirable (Daly, 1991). On top of that, degrowthers remind us that it would be impossible, with current technologies, to reach Western levels of consumption for everyone only based on renewable energy.

A wind-hydro-solar economy could only support much smaller economies, and a transition to renewables would therefore have to be a degrowth transition. Production and consumption levels have thus to be tackled, and the proper way to rethink them can only be world-systemic and class-based, taking into account those who have 'too much' and those who have 'too little'.

C apital has become so mobile that it has been able - with more or less success - to reorganize production worldwide in accordance with profit maximizing opportunities and resource locations. World-system theorists have thus argued that a single transnational global system has emerged, largely administrated by a global ruling class that shares a similar lifestyle and comparable consumption patterns. Accordingly, the degrowth critique applies to the global middle and upper classes regardless of whether they are located in the (so-called) Global North or South. As for the 'global poor', a degrowth scenario would not only leave some environmental space to them to determine their own futures, but also address the issue of the ecological debt that the 'global rich' historically owe to the rest of the world. In this way, "the small movement for degrowth $[\ldots]$ finds natural allies in movements against extraction and for environmental justice in the Global South (movements that confront in practice, rather than in theory, the growth of the insatiable metabolism that supports the imperial mode of living)" (Kallis, 2018: 179-180).

However, some authors have been more skeptical about the 'naturalness' of the alliance. Scheidel and Schaffartzik (2019: 332), for example, argue that environmental justice protesters and degrowthers have not exactly the same aims: while the former often seek to protect "traditional livelihoods and ways of living", the latter seeks "new livelihoods and new ways of living, within alternative societies". Many grassroots resistance movements may indeed start with the defense of a local 'status quo', but this is why a radical ideology able to transcend this limitation is so needed. The key point, from a degrowth perspective, is to transform NIMBY movements ('not in my backyard') into NIABY movements ('not in anyone's backyard'). Degrowth is about taking sustainability seriously everywhere - not only in a few specific places - and this objective 
has radical societal implications. In the longrun, only an integral transition to renewable resources could make this goal possible, and this would fundamentally transform economies as we know them (GeorgescuRoegen, 1975).

The key point is that without a broader degrowth/post-extractivist strategy, antimining conflicts will never fully succeed, and vice versa. Promising examples of such a convergence are already taking place in Ecuador and Germany. In Ecuador, an increasing number of anti-mining movements mobilize an alternative narrative articulated around post-extractivism at the national level (Riofrancos, 2020). In Germany, Ende Gelände ('here and no further') is a large civil disobedience movement seeking the phasing-out of fossil fuels. Every year since 2015 up to 4,000 activists carry out direct actions to stop open-pit coal mines and coal-fired power stations, and they explicitly link their actions to degrowth as a way to achieve climate justice. These examples show that the work of concrete articulation has already started and that similar convergences are likely to gain importance as the twentyfirst century unfolds with a high risk of further multi-dimensional crises.

\section{References}

Bisht, A., Gerber, J.-F. (2017) Ecological Distribution Conflicts (EDCs) over mineral extraction in India: An overview. The Extractive Industries and Society, 4: 548-563.

Conde, M. (2017) Resistance to mining: A review. Ecological Economics, 132: 80-90.

Daly, H. E. (1991) Steady-state economics. Washington DC: Island Press.

Georgescu-Roegen, N. (1975) Energy and economic myths. Southern Economic Journal, 41: 347-381.

Gerber, J.-F., Akbulut, B., Demaria, F., Martínez-Alier, J. (2020) Degrowth and environmental justice: An alliance between two movements? In: Coolsaet, B. (Ed.), Environmental justice: Key issues. London: Routledge.

Gudynas, E. (2013) Transitions to post-extractivism: Directions, options, areas of action. In: Lang, M., Mokrani, D. (Eds.), Beyond development. Amsterdam: TNI.

Kallis, G. (2018) Degrowth. Newcastle upon Tyne: Agenda Publishing.

Riofrancos, T. (2020) Resource radicals: From petro-nationalism to post-extractivism in Ecuador. Durham: Duke University Press.

Scheidel, A., Schaffartzik, A. (2019) A socio-metabolic perspective on environmental justice and degrowth movements. Ecological Economics, 161: 330-333.

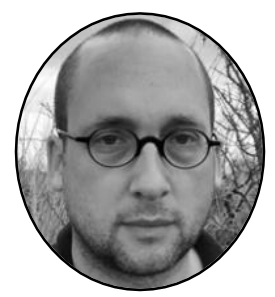

Julien-François Gerber is Assistant Professor at the International Institute of Social Studies in The Hague. After completing his PhD in Barcelona and postdoc at Harvard University, he lived in India and Bhutan before moving to the Low Countries. He has published on the relationships between the economy and the conditions for sustainability, flourishing, alienation and resistance. He is also keen on bridging science and activism and has been active in the degrowth movement. 